\title{
Comparison of gastric body and antral $\mathrm{pH}$ : a 24 hour ambulatory study in healthy volunteers
}

\author{
G Mclauchlan, G M Fullarton, G P CREAN, AND K E L McCOLL \\ From the University Department of Medicine, Western Infirmary, Glasgow and Gastrointestinal Centre, \\ Southern General Hospital, Glasgow
}

SUMMARY Simultaneous ambulatory records of gastric antral and body pH were made over 24 hours in nine healthy volunteers by means of endoscopically positioned and anchored glass electrodes. Intragastric $\mathrm{pH}$ was temporarily raised after the endoscopy with the median pH value 30 minutes after the procedure being $3 \cdot 9$ (range $1 \cdot 5-7 \cdot 0$ ) for the antrum and $4 \cdot 1$ (range $1 \cdot 5-7 \cdot 0$ ) for the body. Daytime pH (median pH value between $1200 \mathrm{~h}$ and $2300 \mathrm{~h}$ ) was lower in the antrum (median $=1.9$, range 1.6-2.6) than in the body (median $=2 \cdot 7$, range $1 \cdot 8-4 \cdot 5)(p<0 \cdot 05)$ and this was because of the rise in $\mathrm{pH}$ on eating being less marked in the antrum than in the body. The median peak pH recorded during the evening meal was only $4 \cdot 1$ (range $2 \cdot 4-6 \cdot 2$ ) in the antrum compared with 6.3 (range 4.4-6.7) in the body $(p<0.01)$. Preprandial pH (median value over the hour prior to the evening meal) was similar in the antrum (median $=1.9$, range $1 \cdot 2-2 \cdot 5)$ and body $(\operatorname{median}=1.9$, range 1·3-2.8). Night-time pH (median pH value between $2300 \mathrm{~h}$ and $0500 \mathrm{~h}$ ) in six subjects remained low and was similar in the antrum $(\operatorname{median}=1 \cdot 4$, $\operatorname{range} 1 \cdot 2-1 \cdot 7)$ and body $(\operatorname{median}=1 \cdot 3$, range $1 \cdot 1-1 \cdot 7)$. In two subjects, however, there were episodes of raised night-time $\mathrm{pH}$ which were more marked in the antrum than in the body. Antral biopsies showed gastritis in four of the nine normal volunteers, which in three was associated with the presence of campylobacter-like organisms. This study shows the significant regional variations in day and night-time intragastric pH.

Over the past decade there has been a dramatic increase in the use of ambulatory $\mathrm{pH}$ monitoring of the upper gastrointestinal tract (GIT) for research purposes and as an aid to diagnosis. Previously, most studies of intragastric $\mathrm{pH}$ depended on the analysis of aspirated gastric juice and had several shortcomings. Gastric aspiration may invoke duodenogastric reflux or stimulate acid secretion ${ }^{\prime 2}$ and may be difficult after a solid meal or during the night when little juice is present in the stomach. ${ }^{3}$ The use of in situ $\mathrm{pH}$ electrodes overcomes these problems and also allows the monitoring of $\mathrm{pH}$ in specific regions of the stomach rather than just giving a mean intragastric value. Because of the problems of maintaining the position of electrodes within the stomach, little is

Address for correspondence: Dr Kenneth E L McColl, University Department of Medicine. Western Infirmary, Glasgow G11 6NT.

Accepted for publication 20 October 1988. known about regional variations in intragastric $\mathrm{pH}$ under conditions of normal daily living. ${ }^{+}$Using a technique developed to allow accurate localisation of electrodes within the upper gastrointestinal tract (GIT), we have monitored simultaneously the $\mathrm{pH}$ of the body and antrum of the stomach over a $24 \mathrm{~h}$ period in nine healthy volunteers.

\section{Methods}

SUBJECTS

Four male and five female healthy volunteers ranging in age from 20-56 years were studied. None had any gastrointestinal tract (GIT) symptoms or history of gastrointestinal problems. Four of the subjects were smokers (numbers 1, 2, 8, and 9).

EXPERIMENTAL DESIGN

The volunteers were admitted to our investigational 
unit for the 24 hours of the study. At approximately $0900 \mathrm{~h}$, and with the subjects fasted since the previous evening, two combined glass electrodes (Radiometer GK2802C) were positioned endoscopically with one anchored to the antral mucosa and the other $10 \mathrm{~cm}$ proximal in the body of the stomach. On withdrawal of the endoscope the electrodes were connected to a Digitrapper Mark II Gold (Synectics) solid state instrument which records the $\mathrm{pH}$ from each electrode every four seconds. On recovery from the sedation, the subjects were fully ambulatory and the $\mathrm{pH}$ recordings continued until the following morning. They consumed the normal hospital meals consisting of breakfast (taken one hour after the endoscopy), mid-morning tea and biscuit, lunch, mid-afternoon coffee and biscuit, dinner, and evening snack. They went to bed between $2200 \mathrm{~h}$ and $2300 \mathrm{~h}$ and rose between $0600 \mathrm{~h}$ and $0700 \mathrm{~h}$. At the end of the $24 \mathrm{~h}$ recording period the electrodes were withdrawn, with the fixation clips still attached, by traction on the leads.

\section{ENDOSCOPIC PROCEDURE}

The technique of anchoring the electrodes in position endoscopically has been comprehensively described in a previous publication.' The two electrodes are attached to each other by Micropore tape so that one is $10 \mathrm{~cm}$ distal to the other and two short loops of nylon thread are attached to the distal electrode. The electrodes are then passed orogastrically alongside a wide channel endoscope (Olympus IT10) and the distal electrode secured in the antrum by clipping both nylon loops to the mucosa using a clip fixing device (Olympus HX-2L). At the time of the endoscopy a biopsy of the antrum was taken for histological examination. All subjects received Midazolam (Hypnovel) $4 \mathrm{mg}$ iv immediately before endoscopy.

The electrodes were calibrated in buffers of $\mathrm{pH}$ 7.01 (Synectics 5001) and pH 1.07 (Synectics 5002) at the start and end of each recording. The clip fixing device and the electrodes were sterilized by immersion in $2 \%$ glutaraldehyde for one hour.

pH ANALYSIS

The data from the Digitrapper were stored on an Amstrad PC 1512 microcomputer. Detailed analysis was done of daytime and night-time $\mathrm{pH}$. Daytime $\mathrm{pH}$ was taken as $1200 \mathrm{~h}-2300 \mathrm{~h}$ as the period before $1200 \mathrm{~h}$ was affected by the endoscopic procedure. Night-time $\mathrm{pH}$ was taken as $2300 \mathrm{~h}-0500 \mathrm{~h}$ so that it included only that time when patients were recumbent in bed. The $\mathrm{pH}$ changes associated with the evening meal and with the endoscopy were analysed in greater detail. The Gastrosoft software package (Synectics) was used to obtain median $\mathrm{pH}$ values for each individual over the different time periods studied. Statistical significance of differences between the values for the antrum and body was assessed using the Wilcoxon's signed-rank test for paired data.

HISTOLOGY

The gastric biopsies were examined in a single blind fashion using hacmatoxylin and cosin stain. Campylobacter-like organisms were identified by the fast cresyl violet stain.

Each subject gave written informed consent to the study which was approved by the Southern General Hospital Ethical Committee.

\section{Results}

In each subject the electrodes were confirmed to have remained firmly anchored in place by observing transient resistance to dislodgement on removal of the electrodes and by the presence of fresh blood and tissue in the retrieved clips. The drift of the electrodes over the $24 \mathrm{~h}$ recording period was negligible with the end calibration values always being within $0.15 \mathrm{pH}$ units of the initial values. Malfunction of the recording equipment prevented analysis of the daytime $\mathrm{pH}$ in one subject and of the night-time $\mathrm{pH}$ in another subject.

\section{PH IMMEDIATELY AFTER ENDOSCOPY}

The $\mathrm{pH}$ of the antrum and body was higher immediately after the endoscopy compared with other fasting periods. Thirty minutes after the placement procedure, the antral $\mathrm{pH}$ ranged from $1 \cdot 5-7 \cdot 0)$ $($ median $=3.9)$ and body $\mathrm{pH}$ from 1.5-7.0 $($ median $=$ $4 \cdot 1$ ). In contrast, preprandial antral $\mathrm{pH}$ (median $\mathrm{pH}$ value for each individual over the hour before the evening meal) ranged from $1.2-2.5($ median $=1.9)$ and preprandial body $\mathrm{pH}$ from $1 \cdot 3-2 \cdot 8(\operatorname{median}=1 \cdot 9)$ (Table 1). After the endoscopy, the median time for the $\mathrm{pH}$ to return to preprandial values was 54 minutes (range 0-110) for the antrum and 57 minutes (range 0-120) for the body. There was no significant difference between the $\mathrm{pH}$ readings in the antrum and body after endoscopy. The $\mathrm{pH}$ tracing of subject no 3 illustrating the effect of the endoscopy is shown in Figure 1.

\section{DAYTIME PH}

In seven of the eight subjects, the daytime $\mathrm{pH}-$ that is, median $\mathrm{pH}$ value between $1200 \mathrm{~h}$ and $2300 \mathrm{~h}$, which included prandial and postprandial periods was lower in the antrum than in the body (Table 2). The median daytime $\mathrm{pH}$ of the eight subjects was 2.7 (range 1.8-4.5) for the body compared with 1.9 (range $1 \cdot 6-2 \cdot 6)$ for the antrum $(\mathrm{p}<0 \cdot 05)$. Likewise, 
Table 1 Effect of evening meal on the pH of the gastric body and antrum

\begin{tabular}{|c|c|c|c|c|c|c|}
\hline Subject no & & $\begin{array}{l}\text { Preprandial } \\
\mathrm{pH}^{\dagger}\end{array}$ & $\begin{array}{l}\text { Delay in } \mathrm{pH} \\
\text { rise after starting } \\
\text { meal }\end{array}$ & $\begin{array}{l}\text { Time to reach peak } \\
\text { pH after starting } \\
\text { meal (min) }\end{array}$ & $\begin{array}{l}\text { Peak pH during } \\
\text { meal }\end{array}$ & $\begin{array}{l}\text { Time to return to } \\
\text { basal pH after starting } \\
\text { meal (min) }\end{array}$ \\
\hline 1 & $\begin{array}{l}\text { Body } \\
\text { Antrum }\end{array}$ & $\begin{array}{l}2 \cdot 2 \\
2 \cdot 0\end{array}$ & $\begin{array}{l}45(\mathrm{sec}) \\
30(\mathrm{~min})\end{array}$ & $\begin{array}{l}21 \\
45\end{array}$ & $\begin{array}{l}4 \cdot 4 \\
2 \cdot 4\end{array}$ & $\begin{array}{l}210 \\
210\end{array}$ \\
\hline 2 & $\begin{array}{l}\text { Body } \\
\text { Antrum }\end{array}$ & $\begin{array}{l}2 \cdot 8 \\
2 \cdot 5\end{array}$ & $\begin{array}{l}16(\mathrm{sec}) \\
11(\mathrm{~min})\end{array}$ & $\begin{array}{l}12 \\
28\end{array}$ & $\begin{array}{l}6 \cdot 6 \\
4 \cdot 5\end{array}$ & $\begin{array}{l}63 \\
86\end{array}$ \\
\hline 3 & $\begin{array}{l}\text { Body } \\
\text { Antrum }\end{array}$ & $\begin{array}{l}1.4 \\
1.9\end{array}$ & $\begin{array}{l}8(\mathrm{sec}) \\
1(\mathrm{~min})\end{array}$ & $\begin{array}{l}24 \\
43\end{array}$ & $\begin{array}{l}6 \cdot 4 \\
4 \cdot 1\end{array}$ & $\begin{array}{r}95 \\
126\end{array}$ \\
\hline 4 & $\begin{array}{l}\text { Body } \\
\text { Antrum }\end{array}$ & $\begin{array}{l}1.4 \\
1.5\end{array}$ & $\begin{array}{c}240(\mathrm{sec}) \\
6(\mathrm{~min})\end{array}$ & $\begin{array}{l}20 \\
40\end{array}$ & $\begin{array}{l}6 \cdot 6 \\
4 \cdot 2\end{array}$ & $\begin{array}{l}127 \\
136\end{array}$ \\
\hline 5 & $\begin{array}{l}\text { Body } \\
\text { Antrum }\end{array}$ & $\begin{array}{l}2 \cdot 1 \\
2 \cdot 1\end{array}$ & $\begin{array}{c}60(\mathrm{sec}) \\
6(\mathrm{~min})\end{array}$ & $\begin{array}{r}7 \\
13\end{array}$ & $\begin{array}{l}6 \cdot 2 \\
4 \cdot 5\end{array}$ & $\begin{array}{l}121 \\
201\end{array}$ \\
\hline 6 & $\begin{array}{l}\text { Body } \\
\text { Antrum }\end{array}$ & $\begin{array}{l}2 \cdot 2 \\
2 \cdot 2\end{array}$ & $\begin{array}{c}16(\mathrm{sec}) \\
9(\mathrm{~min})\end{array}$ & $\begin{array}{l}16 \\
53\end{array}$ & $\begin{array}{l}6 \cdot 7 \\
6 \cdot 2\end{array}$ & $\begin{array}{r}130 \\
94\end{array}$ \\
\hline 7 & $\begin{array}{l}\text { Body } \\
\text { Antrum }\end{array}$ & $\begin{array}{l}1.8 \\
1.6\end{array}$ & $\begin{array}{c}16(\mathrm{sec}) \\
6(\mathrm{~min})\end{array}$ & $\begin{array}{r}8 \\
30\end{array}$ & $\begin{array}{l}4 \cdot 4 \\
2 \cdot 4\end{array}$ & $\begin{array}{l}120 \\
126\end{array}$ \\
\hline 8 & $\begin{array}{l}\text { Body } \\
\text { Antrum }\end{array}$ & $\begin{array}{l}1 \cdot 3 \\
1 \cdot 2\end{array}$ & $\begin{array}{c}50(\mathrm{sec}) \\
2(\mathrm{~min})\end{array}$ & $\begin{array}{r}6 \\
34\end{array}$ & $\begin{array}{l}4 \cdot 4 \\
3 \cdot 0\end{array}$ & $\begin{array}{l}45 \\
37\end{array}$ \\
\hline Median values & $\begin{array}{l}\text { Body } \\
\text { Antrum }\end{array}$ & $\begin{array}{l}1.9 \\
1.9\end{array}$ & $\begin{array}{l}30(\mathrm{sec}) \\
6(\mathrm{~min})^{*}\end{array}$ & $\begin{array}{l}14 \\
37^{*}\end{array}$ & $\begin{array}{l}6 \cdot 3 \\
4 \cdot 1^{+}\end{array}$ & $\begin{array}{l}120 \\
126\end{array}$ \\
\hline
\end{tabular}

*Significantly greater than body with $\mathrm{p}=0.01$; ${ }^{+}$Significantly less than body with $\mathrm{p}<0.01 ; \dagger$ Preprandial $\mathrm{pH}$ represents the median value over the hour before the evening meal.
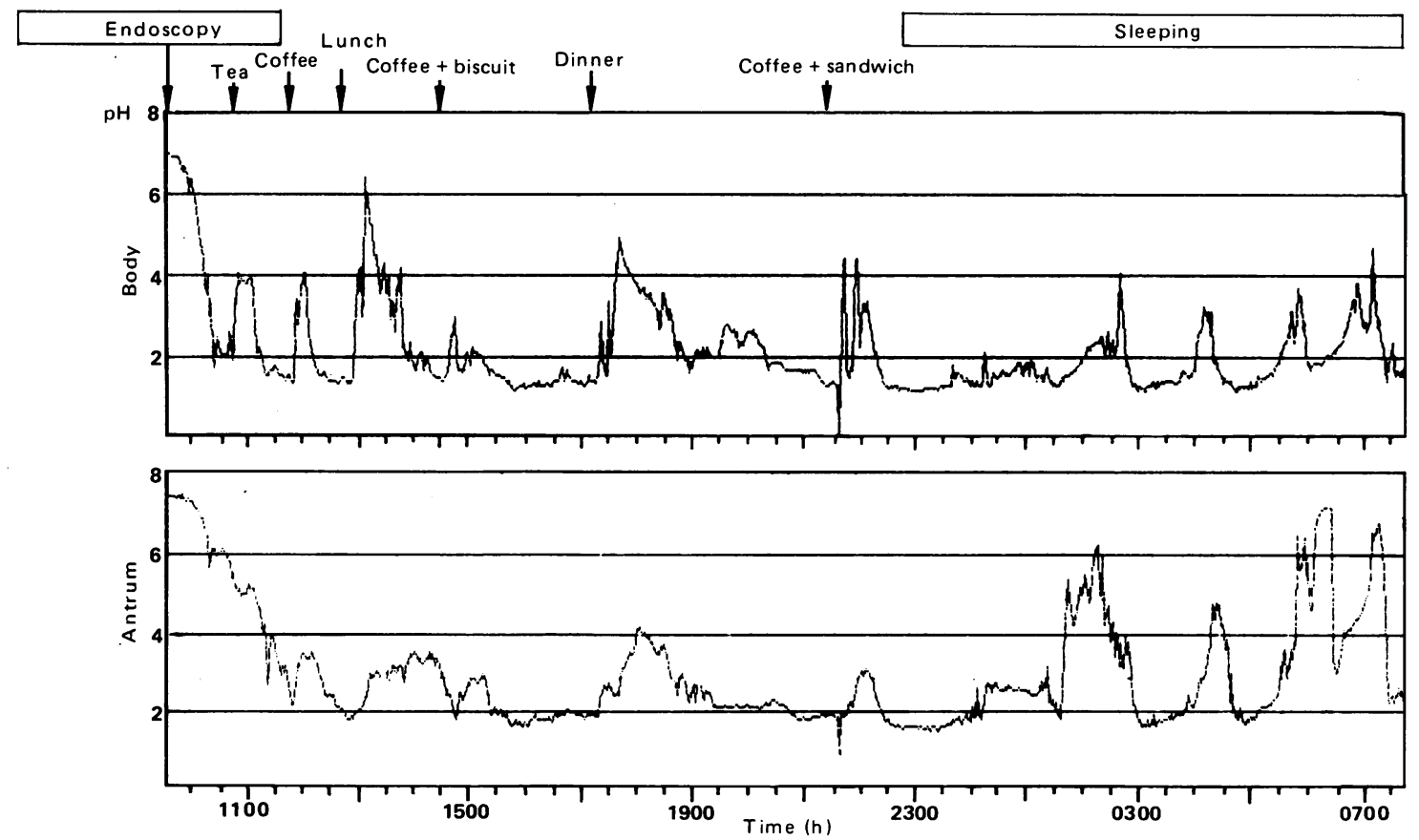

Fig. 1 Twenty four hour ambulatory simultaneous $p H$ recordings of gastric antrum and body in subject number 3 . This shows the increased $\mathrm{pH}$ after the endoscopy and the fact that eating increases body $\mathrm{pH}$ more than antral pH. In contrast, episodes of increased nocturnal $\mathrm{pH}$ are more pronounced in the antrum than in the body. 
Table 2 Daytime and night-time pH of gastric body and antrum

\begin{tabular}{|c|c|c|c|c|c|c|c|}
\hline \multirow[b]{2}{*}{ Subject no } & & \multicolumn{2}{|c|}{ Daytime $(1200 h-2300 h)$} & \multicolumn{2}{|c|}{ Night-time $(2300 h-0500 h)$} & \multicolumn{2}{|c|}{ Day+night $(1200 h-0500 h)$} \\
\hline & & Median $p H$ & $\% p H<3$ & Median $p H$ & $\% p H<3$ & Median $p H$ & $\% p H<3$ \\
\hline \multirow[t]{2}{*}{1} & Body & $3 \cdot 2$ & 46 & $1 \cdot 6$ & 100 & $2 \cdot 7$ & 65 \\
\hline & Antrum & $2 \cdot 2$ & 92 & 1.5 & 97 & 1.8 & 94 \\
\hline \multirow[t]{2}{*}{2} & Body & $2 \cdot 5$ & 27 & 1.7 & 88 & $2 \cdot 3$ & 48 \\
\hline & Antrum & $2 \cdot 4$ & 95 & $1 \cdot 7$ & 89 & $2 \cdot 2$ & 91 \\
\hline \multirow[t]{2}{*}{3} & Body & $2 \cdot 0$ & 81 & $2 \cdot 0$ & 89 & $2 \cdot 0$ & 84 \\
\hline & Antrum & $1 \cdot 8$ & 83 & $3 \cdot 2$ & 60 & $2 \cdot 2$ & 75 \\
\hline \multirow[t]{2}{*}{4} & Body & 1.8 & 79 & $1 \cdot 3$ & 100 & 1.6 & 87 \\
\hline & Antrum & 1.9 & 77 & $1 \cdot 5$ & 98 & $1 \cdot 6$ & 85 \\
\hline \multirow[t]{2}{*}{5} & Body & $3 \cdot 1$ & 56 & $3 \cdot 6$ & 46 & $3 \cdot 2$ & 53 \\
\hline & Antrum & $2 \cdot 6$ & 64 & $4 \cdot 4$ & 34 & $3 \cdot 1$ & 53 \\
\hline \multirow[t]{2}{*}{6} & Body & $3 \cdot 0$ & 63 & $1 \cdot 1$ & 100 & $1 \cdot 6$ & 70 \\
\hline & Antrum & $2 \cdot 0$ & 89 & $1 \cdot 2$ & 100 & $1 \cdot 7$ & 93 \\
\hline \multirow[t]{2}{*}{7} & Body & 1.9 & 87 & $1 \cdot 1$ & 100 & 1.7 & 93 \\
\hline & Antrum & 1.7 & 100 & $1 \cdot 2$ & 84 & $1 \cdot 6$ & 94 \\
\hline \multirow[t]{2}{*}{8} & Body & $4 \cdot 5$ & 39 & - & - & - & - \\
\hline & Antrum & 1.6 & 96 & - & - & - & - \\
\hline \multirow[t]{2}{*}{9} & Body & - & - & $1 \cdot 3$ & 100 & - & - \\
\hline & Antrum & - & - & $1 \cdot 3$ & 100 & - & - \\
\hline \multirow[t]{2}{*}{ Median values } & Body & $2 \cdot 7$ & 59 & $1 \cdot 4$ & 100 & $2 \cdot 0$ & 70 \\
\hline & Antrum & $1.9 *$ & $90^{+}$ & $1 \cdot 5$ & $93^{*}$ & $1 \cdot 8$ & 91 \\
\hline
\end{tabular}

*Significantly less than body with $\mathrm{p}<0 \cdot 05$; ' Significantly greater than body with $\mathrm{p}<0 \cdot 05$.

the percentage daytime $\mathrm{pH}<3$ was higher for the antrum (median $=90 \%)$ than for the body (median $=$ $59 \%)(\mathrm{p}<0 \cdot 05)$.

More detailed analysis showed that the difference in daytime $\mathrm{pH}$ between the body and antrum was not caused by differences in the preprandial $\mathrm{pH}$ but in the $\mathrm{pH}$ response to meals. The preprandial $\mathrm{pH}$ (median value over the hour before starting the evening meal) of the eight subjects ranged from $1 \cdot 3$ to $2 \cdot 8$ (median= $1.9)$ for the body which was similar to the values for the antrum (range, 1.2-2.5; median $=1 \cdot 9$ ) (Table 1$)$. On commencing to eat, the antral $\mathrm{pH}$ was later than the body $\mathrm{pH}$ in starting to rise and also in reaching its peak $\mathrm{pH}$ (Table 1). The median time for the body $\mathrm{pH}$ to begin to rise after starting the evening meal was 30 seconds (range 8-60 seconds) compared with six minutes (range two to 30 minutes) for the antrum $(p=0.01)$, and the median time for the body to reach its peak prandial $\mathrm{pH}$ was 14 minutes (range six to 24 minutes) compared with 37 minutes (range 13-53 minutes) for the antrum $(p=0 \cdot 01)$. The two regions of the stomach also differed with respect to the peak $\mathrm{pH}$ achieved during the evening meal. The peak $\mathrm{pH}$ values for the body ranged from $4 \cdot 4-6 \cdot 7$ (median $=$ $6 \cdot 3)$ and for the antrum $2 \cdot 4-6 \cdot 2$ (median=4.1) $(\mathrm{p}<0.01)$. The time for the $\mathrm{pH}$ to return to preprandial levels after starting the evening meal was similar in the body (median=120 minutes) and antrum (median $=126$ minutes). The $\mathrm{pH}$ tracing of subject no 7 illustrating the differing $\mathrm{pH}$ response of the body and antrum on eating is shown in Figure 2.

NIGHT-TIME $\mathrm{pH}$

The night-time $\mathrm{pH}$ (median value between $2300 \mathrm{~h}$ and $0500 \mathrm{~h}$ ) of the individual subjects varied from $1 \cdot 2-4.4($ median $=1.5)$ for the antrum and was similar for the body (range $1 \cdot 1-3 \cdot 6$, median $=1 \cdot 4$ ). There were clear differences, however, in the night-time $\mathrm{pH}$ between the eight individuals. In six the night-time $\mathrm{pH}$ showed little, if any, fluctuation with the $\mathrm{pH}$ of the body being less than 3 for more than $88 \%$ of the time and the $\mathrm{pH}$ of the antrum being less than 3 for more than $84 \%$ of the time (Table 2). Two of the female subjects (numbers 3 and 5) showed a different pattern having well defined episodes of raised antral and body $\mathrm{pH}$ throughout the night. On each of the occasions, the rise in $\mathrm{pH}$ was evident in both electrodes although usually more marked and prolonged in the antral electrode (Fig. 1). The duration of the episodes of raised $\mathrm{pH}$ recorded by the antrum electrodes in these two patients varied from 40-90 minutes and the peak $\mathrm{pH}$ reached during the episodes varied from 3.5-7. The episodes of raised $\mathrm{pH}$ were more pronounced in patient number 5 who was the 

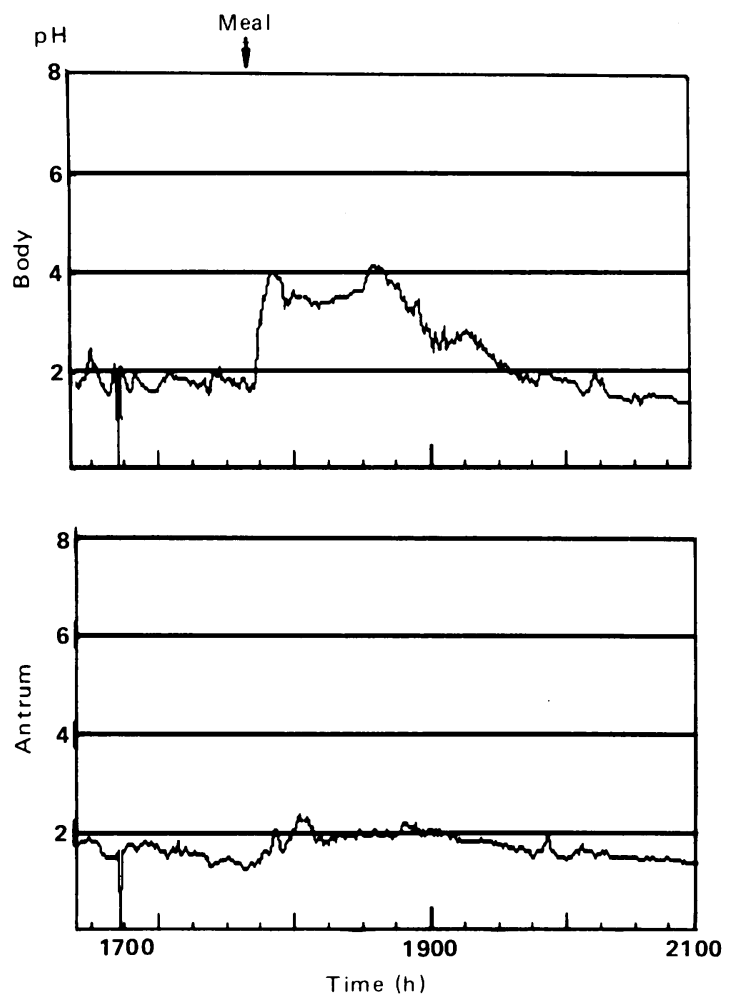

Fig. 2 Effect of evening meal on the $\mathrm{pH}$ of the gastric antrum and body in subject number 7 whose tracings are representative of the subjects studied.

oldest patient studied (56 years) than in patient number 3 who was the second oldest ( 45 years).

DAYTIME AND NIGHT-TIME $\mathrm{PH}$ COMBINED When the median $\mathrm{pH}$ values were calculated for each individual for the entire daytime and night-time period $(1200 \mathrm{~h}-0500 \mathrm{~h})$ there was no significant difference between the body and antrum, the values ranging from $1 \cdot 6-3 \cdot 2($ median $=2 \cdot 0)$ for the former and $1 \cdot 6-3 \cdot 1($ median $=1 \cdot 8)$ for the latter (Table 2$)$.

ANTRAL BIOPSIES

The histology of the antral biopsies was normal in five of the subjects but in four (nos 2,3,5, and 9) there was evidence of chronic superficial gastritis with infiltration of lymphocytes and plasma cells in the lamina propria. Campylobacter-like organisms were present in three (nos 2,3, and 9) of these four subjects with gastritis. Both of the subjects with periods of raised night-time $\mathrm{pH}$ had gastritis and in subject number 5 who had the most pronounced episodes of raised night-time $\mathrm{pH}$ the gastritis was not associated with Campylobacter-like organisms.

\section{Discussion}

The first unexpected finding from this study was that intragastric $\mathrm{pH}$ when measured using in situ glass electrodes, is markedly increased after upper gastrointestinal endoscopy and may reach neutral values. The reason for this is not clear. Midazolam, which was the only premedication used, is not known to interfere with gastric secretion or motility. The high $\mathrm{pH}$ readings could be related to the aspiration of the gastric juice and insufflation of air during the endoscopic examination. In addition, retching during the endoscopy is likely to cause duodenogastric reflux of alkaline juices. Whatever the explanation, the observations should be borne in mind if $\mathrm{pH}$ readings are taken for diagnostic or research purposes at endoscopy as they do not reflect normal fasting gastric values. Because of the effect of the endoscopic procedure, detailed analysis of our data was started at $1200 \mathrm{~h}$, three hours after the procedure.

The premeal daytime $\mathrm{pH}$ was similar in the antrum and body but the rise in $\mathrm{pH}$ with eating was more immediate and more marked in the body. Though there has been no previous study of regional variations in gastric $\mathrm{pH}$ using fixed electrode position, Fimmel et al monitored body and antral $\mathrm{pH}$ in four healthy volunteers using electrodes positioned fluoroscopically. ${ }^{.7}$ They found also that the $\mathrm{pH}$ of the two regions was similar during fasting and that eating resulted in a more marked rise in $\mathrm{pH}$ in the body than in the antrum. Intragastric $\mathrm{pH}$ rises on eating because of the buffering effect of the food exceeding the meal stimulated increase in acid secretion. As the latter does not peak until 60-90 minutes after starting to eat, ${ }^{x}$ the rise in intragastric $\mathrm{pH}$ is most pronounced shortly after starting to eat when the buffering effect of the food predominates. In the present study the rise in gastric body $\mathrm{pH}$ was maximum 14 minutes after starting to eat, and then fell even though gastric emptying of a solid meal does not usually begin until 27 minutes after starting the meal. ${ }^{4}$ This subsequent fall in $\mathrm{pH}$ can be explained by the increasing acid output overwhelming the buffering capacity of the food. Our finding that the rise in $\mathrm{pH}$ was later and less in the antrum compared with the body can be explained by previous scintigraphic observations that a solid meal is initially concentrated in the body and then 'fed' into the antrum. ${ }^{4}$ By the time the food reaches the antrum its buffering effect will be largely overcome by the increasing acid secretion. In addition the slower rate of delivery of the food into the antrum will minimise its buffering effect. The differences in gastric body and antral $\mathrm{pH}$ observed after the solid meal are consistent with the observation made by Eyerly and Breuhaus 50 years ago that the stomach acts more like a hopper than a churn." 
The night-time $\mathrm{pH}$ in most of the subjects was low and showed little fluctuation consistent with the fasting state. In the two oldest subjects studied, however, the $\mathrm{pH}$ rose considerably for variable periods of time throughout the night. The fact that the distal electrode was secured in the antrum and also that the rise in $\mathrm{pH}$ affected both electrodes means that the changes could not be explained by displacement of the electrode into the duodenum or oesophagus. Interestingly, the rise in $\mathrm{pH}$ in the antrum was usually more marked than that in the more proximal body electrode, this pattern being opposite to that occurring after a meal. These observations would be consistent with the rises in gastric $\mathrm{pH}$ being the result of duodenogastric reflux of alkaline juices. Fimmel et al studied $24 \mathrm{~h}$ intragastric $\mathrm{pH}$ using a single unfixed electrode in normal volunteers and noted similar periods of elevated $\mathrm{pH}$ in a proportion of their subjects which they also attributed to duodenogastric reflux. ${ }^{5}$ Previous studies have showed duodenogastric reflux in healthy volunteers both in the fasting state and after meals. ${ }^{.1-14}$

In spite of the fact that all our patients were asymptomatic healthy volunteers, four of the nine antral biopsies showed evidence of gastritis and in three of these Campylobacter-like organisms were also identified. This is consistent with the study by Jones $e t$ al which demonstrated circulating antibodies to Campylobacter in $16-49 \%$ of healthy volunteers. ${ }^{15}$ A high correlation exists between the antibody and the presence of the bacterium and gastritis in antral biopsies. ${ }^{16}$ Duodenogastric reflux has been suggested as a cause of gastritis ${ }^{17-19}$ and in this study the two subjects with episodes of raised nocturnal gastric $\mathrm{pH}$ both had evidence of gastritis. In the subject with the most marked episodes of raised nocturnal $\mathrm{pH}$, the gastritis was not associated with Campylobacter.

By showing differences in the $\mathrm{pH}$ of the antrum and body of the stomach during the day and night this study emphasises the fact that intragastric $\mathrm{pH}$ is not a single entity.

The authors wish to acknowledge the helpful advice of Dr Michael Lucas, Department of Physiology, University of Glasgow, in the preparation of this manuscript.

\section{References}

1 Eyerly JB. Comparative $\mathrm{pH}$ values within the stomach, pylorus and duodenum in antacid therapy. Am J Dig Dis 1940; 7: 431-4.

2 Schlotthauer B, Noller HG. Ergebnisverfalschungen bei der Magenuntersuchung, bedingt durch die Schlauchtechnik. Munchner Med Wochenschr 1964; 17: 785-9.

3 Levin E, Kirsner JB, Palmer WL, Butler C. The variability and periodicity of the nocturnal gastric secretion in normal individuals. Gastroenterology 1948; 10: 939-51.

4 Emde C, Garner A, Blum AL. Technical aspects of intraluminal pH-metry in man: current status and recommendations. Gut 1987; 28: 1177-88.

5 McLauchlan G, Buchanan NMM, Crean GP, McColl KEL. An endoscopic procedure for accurate localisation of intraluminal pH electrodes. Endoscopy 1987; 19: $124-6$.

6 Fimmel CJ, Etienne A, Gilluffo T, et al. Long-term ambulatory gastric $\mathrm{pH}$ monitoring: validation of a new method and effect of $\mathrm{H} 2$-antagonists. Gastroenterology 1985; 88: 1842-51.

7 Bauerfeind P, Cilluffo T, Fimmel CJ, et al. Die intragastrale Langzeit-pH-Metrie. Schweiz Med Wochenschr 1985; 115: 1630-41.

8 Fordtran JS, Walsh JH. Gastric acid secretion rate and buffering content of the stomach after eating. $J$ Clin Invest 1973; 52: 645-57.

9 Robinson PH, Clarke M, Barrett J. Determination of delayed gastric emptying in anorexia nervosa and bulimia nervosa. Gut 1988; 29: 458-64.

10 Eyerly JB, Breuhaus HC. A method of measuring acidity and protein digestion within the human stomach. Am J Dig Dis 1939; 6: 187-92.

11 Muller-Lissner SA, Fimmel CJ, Sonnenberg A, et al. Novel approach to quantify duodenogastric reflux in healthy volunteers and in patients with type 1 gastric ulcer. Gut 1983; 24: 510-8.

12 Keane FB, Dimagno EP, Malagelada JR. Duodenogastric reflux in humans: its relationship to fasting antroduodenal motility and gastric, pancreatic, and biliary secretion. Gastroenterology 1981; 81: 726-31.

13 Heading RC. Duodenogastric reflux. Gut 1983; 24: 507-9.

14 Hostein J, Bost R, Faure H, Lachet B, Fournet J. Valeur diagnostique de la pHmetrie gastrique au cours du reflux duodeno-gastrique. Gastroenterol Clin Biol 1987; 11: 206-11.

15 Jones DM, Eldridge J, Fox AJ, Sethi P, Whorwell PJ. Antibody to the gastric campylobacter-like organism ('Campylobacter pyloridis') - clinical correlations and distribution in the normal population. J Med Microbiol 1986; 22: 57-62.

16 Jones DM, Lessells AM, Eldridge J. Campylobacterlike organisms on the gastric mucosa: culture, histological and serological studies. J Clin Pathol 1984; 37: $1002-6$.

17 O'Connor HJ, Wyatt JI, Dixon MF, Axon ATR. Campylobacter like organisms and reflux gastritis. J Clin Pathol 1986; 39: 531-4.

18 Niemela S, Karttunen T, Heikkila J, Lehtola J. Characteristics of reflux gastritis. Scand J Gastroenterol 1987; 22: 349-54.

19 Ritchie IJP. Alkaline reflux gastritis: a critical reappraisal. Gut 1984; 25: 975-87. 